\title{
Solidarity and Microfinance*
}

\author{
Vittoria Cerasi $^{\dagger} \quad$ Lucia Dalla Pellegrina ${ }^{\ddagger}$
}

This version: 20 april 2012

\begin{abstract}
In this paper we analyze the role of peer solidarity in fostering productive investments in the context of microfinance. When there is asymmetric information between lenders and borrowers and loans are not collateralized, borrowers may divert loans towards current consumption rather than investing in production. We assume that solidarity is accorded by a network of individuals close enough to the borrower (peers) so as to share private information about hidden effort in the productive project. The model shows that peer solidarity might have contrasting effects on the effort in the productive investment. On the one hand, since solidarity transfers are contingent on the effort, they increase borrower's incentive to invest. On the other hand, solidarity tranfers decrease the marginal utility of future consumption at the expense of productive investment. The predictions of the model are tested on households enrolled in micro-lending programs who were surveyed in Bangladesh by the World Bank during the period 1991-1992. Empirical findings suggest a positive relationship between the financial capability of borrowers' solidarity network and the share of loans invested in productive activities.
\end{abstract}

Keywords: Micro-Finance; Social Networks; Intertemporal Consumption.

JEL Classification: O16 (Economic Development: Financial Markets; Saving and Capital Investment); G21 (Micro Finance Institutions).

${ }^{*}$ We appreciated comments from participants at the Second European Research Conference on Microfinance in Groningen (June 2011) and especially from two anonimous referees.

${ }^{\dagger}$ Corresponding author: Università degli Studi di Milano Bicocca, Department of Statistics, Via Bicocca degli Arcimboldi 8, 20126 Milano, Italy. Phone: +39-02-6448.5821, fax: +39-02-6448.5878, E-mail: vittoria.cerasi@unimib.it.

${ }^{\ddagger}$ Università degli Studi di Milano Bicocca, Department of Statistics, Via Bicocca degli Arcimboldi 8, 20126 Milano, Italy (and Paolo Baffi Centre on Central Banking and Financial Regulation, Bocconi University). E-mail: lucia.dallapellegrina@unibocconi.it. 


\section{Introduction}

In microfinance physical collateral is substituted with other mechanisms that foster loan repayment, such as group liability, peer monitoring and social pressure. There is evidence that these mechanisms work effectively in several contexts where microfinance is widespread.

In principle, weak incentives to repay loans may be particularly critical in microfinance programs that target low income households who lack physical guarantees (see for example Ghosh et al., 2000). Poverty may induce a myopic attitude towards future, in part explained by shorter life expectancy, higher discouragement and vulnerability, or by the lack of social insurance or savings that can be used as buffers against unexpected shocks. These factors undermine the incentive to invest in productive projects and thus the ability to repay loans.

One important feature ensuring the success of microfinance, and especially of group-lending, is peer screening at the stage of group formation (Ghatak, 1999 and 2000; Wydick, 1999; Wenner, 1995). However, this ex-ante mechanism may be insufficient to avoid ex-post opportunism (Stiglitz, 1990), as for instance diversion of borrowed funds towards current consumption which impairs longer term productive projects (Menon 2004; Armendariz and Morduch 2005, Giné et al., 2006).

Other mechanisms, based on social pressure, have been proposed as a way to overcome ex-post moral hazard. In the literature on social sanctions (see for example Besley and Coate, 1995) punishment in case of default, such as for example the threat to denounce peer misbehavior to the village community, is imposed by individuals who are close to the borrower.

In this paper we investigate peer solidarity, a slightly different mechanism based on social pressure, as a way to reduce opportunistic behavior by borrowers. Peer solidarity can be thought as a form of mutual insurance among individuals (typically relatives) who provide financial transfers in case of negative shocks in order to partially or fully compensate the losses. Our approach is similar 
to that of social sanctions ${ }^{1}$, since transfers are denied to the borrower in case of misbehavior and are provided by those who are best informed about the borrower's actions. It departs, however, in that the denial of solidarity does not necessarily come from individuals who have been directly damaged by a defaulting borrower. ${ }^{2}$ What is essential is that solidarity providers must be close enough to the borrower to be able to share private information with her. In fact we model solidarity transfers as a function of the investment in production, which we assume being observable by individuals who are close to the borrower but not by third parties.

We believe that, although it has not received enough attention in the microfinance literature, peer solidarity might be relevant as suggested by anecdotal evidence. ${ }^{3}$ We therefore analyze the role of peer solidarity in a model where lenders do not observe the share of the loan invested in a risky, although productive, project, but the borrower may divert it to current consumption. Peers, who observe this share, may condition their transfers on the investment. We show that, there may be two countervailing effects of solidarity. On the one hand, greater solidarity induces borrowers to invest more in the risky project since the expected return from the investment is enhanced by the transfer received in the default state; but on the other hand, solidarity transfers might discourage effort due to the fact that the reduced marginal utility of future consumption induces the borrower to shift income in favour of current consumption for the

\footnotetext{
1 "Social sanctions may imply exclusion from other financial transactions (such as informal insurance) or other economic or social penalties" (Nissanke, 2002). Even if the term "other financial transactions" may refer to future loans and thus can be easily extended to solidarity transfers.

${ }^{2}$ As far as social sanctions are concerned, some authors (see for example Besley and Coate, 1995 ) interpret them as being imposed by members of the same lending group. Others (see for example Nissanke, 2002) state that defaulters are instead subject to effective and severe sanctions by the whole community, in the form of social stigma. The reasons why individuals who are not necessarily group members impose sanctions, or deny solidarity, could be many. For instance, their community may be indirectly damaged through a loss of reputation. They can also be driven by socially disciplining features rather than the simple willingness to strike back.

${ }^{3}$ Officers from several Microfinance Institutions (MFIs, hereafter), for example, encourage solidarity. "In the weekly meetings, FINCA employees explicitly encourage clients to develop solidarity, both to enhance their social capital as well as to monitor and enforce the loans" (Karlan, 2005).
} 
well known argument of intertemporal consumption smoothing. Our model predicts that solidarity transfers might have overall a positive effect on the amount of productive investments, the greater is their marginal revenue, measured by the rate of intertemporal substitution and investment return, or the smaller is risk aversion. We leave to the empirical test the task of measuring the actual effect of peer solidarity on productive investments.

We test the predictions of the model on a sample of households surveyed in Bangladesh by the World Bank during the period 1991-1992. As explained in Dalla Pellegrina (2011) there are still important reasons to investigate Bangladesh in the Nineties. Although some MFIs have recently introduced also individual lending, they still maintain the previous organizational structure in their supply of loans (Barua and Dowla, 2006), so that relatively time-invariant features such as borrowers' incentives may have not significantly changed (Armendariz and Morduch, 2005). Furthermore, the traditional lending model of the Nineties, dominant in our dataset, is still adopted in many developing countries, and especially in Africa (see for example Basu et. al, 2004, and Hermes et al., 2005).

We assume that the degree of solidarity that borrowers can access is, ceteris paribus, proportional to the dimension of their network of wealthier relatives, regardless of the actual amount of the transfers they receive. This allows us to account for the incentives generated by solidarity transfers without having to deal with the actual ability of borrowers to obtain external resources. ${ }^{4}$

We find evidence that having access to a larger network of solidarity increases the share of funds devoted to productive investments. Our paper, to our knowledge, is the first to analyze within a formal model and to provide empirical evidence on the reasons why solidarity may be relevant for microfinance.

Notice, however, that there could be drawbacks of solidarity on loan repayments due to the incentive to default strategically (ex-post moral hazard). In other words, when debt repayment is non enforceable due to asymmetric information between lender and borrowers (see for example Armendariz and

\footnotetext{
${ }^{4}$ Actual transfers, on the other hand, may be correlated with non observable variables affecting borrowers' incentives to invest in production. Hence, we do not use actual transfers when testing the effects of solidarity, to avoid identification problems.
} 
Morduch, 2000, on social sanctions), the borrower may decide to lie and claim default whenever the cash granted by the solidarity network is greater than the income of the project. We do not directly measure whether actual transfers reduce repayment rates, however we find that their effect on productive investments is not significant.

In addition, dynamic incentives based on small repeated loans and on the threat of non-refinancing is used by MFIs to curb ex-post moral hazard and avoid strategic default. Although we do not explicitly account for repeated lending in the model, we introduce in our regressions a proxy of the importance of future financing, but it proves to be not significant.

The paper is organized as follows. In the next section we present the theoretical model to be tested. Section 3 illustrates the dataset and sets the equations of the empirical model to be estimated. In Section 4 we discuss the results. Section 5 concludes.

\section{The Model}

We consider a two-period model with three dates $(t=0,1,2)$ where an agent maximizes her intertemporal utility. There are risky productive projects in the economy. The agent can decide between consuming in the first period or investing in the productive project and delaying consumption to the second period. We assume that the agent lacks the initial capital to be used as input for production, therefore she has to borrow it from a lender. She borrows a fixed sum $L$ in date 0 . No collateral is required by the lender.

The amount borrowed can be divided into two parts, a share $(1-e) \in[0,1]$ to be consumed at date $1, C_{1}=(1-e) L$, and a share $e$ to be invested in a productive project delivering a revenue at date 2 , such that $C_{1}+I=L$. The productive project is risky: by investing 1 unit in date 1 the borrower obtains $R$ in date 2 with probability $p \in[0,1]$, zero otherwise. Investing in the productive project yields a positive net present value $p R>1$ per unit invested. The loan requires the borrower to repay a face value $D$ to the lender in date 2 only in 
case the project succeeds, zero otherwise, due to limited liability and absence of collateral. Since the share invested $e$ is non observable to outsiders, there is moral hazard between lender and borrower: the borrower may claim to have invested and been unlucky, meanwhile keeping the money for himself. The borrower's choice is between consuming immediately a fraction $(1-e)$ of the loan in date 1 or postponing consumption to date 2 after the productive project has returned a revenue. Consumption in the second period is uncertain due to the risk implicit in the investment which may fail with a positive probability. We assume risk neutrality for the lender, but allow for borrower's risk aversion.

Let us summarize the timing as follows:

In $t=0$ : the agent borrows $L$ units of capital from the lender;

In $t=1$ : the agent invests a fraction $e$ of the loan and consumes a fraction $(1-e)$

In $t=2$ : the productive project returns $R I$ or 0 and the cash-flow is divided between lender and borrower according to the loan contract; the borrower consumes the revenue from the investment after repaying the loan.

The expected utility of consumption is additive in the two periods

$$
E U=u\left(C_{1}\right)+\beta u\left(C_{2}\right)
$$

with an intertemporal preference rate $\beta \in(0,1)$ implying that future consumption must compensate more than proportionally today sacrifice.

Consumption in the second period can be at most the revenue from the investment net of the repayment to the lender in case the project succeeds, that is $p(R I-D)$. Finally, the face value $D$ must fulfil lender's participation constraint, that is the expected return on the loan must be greater enough to recover the capital:

$$
p D \geq L
$$

We introduce now peer solidarity as a form of insurance against bad luck: peers might transfer money to the agent in the unlucky event that the risky investment 
fails. Being closer to the agent, we assume that peers can observe the amount of the effort spent and are willing to provide an increasing amount the greater the agent's effort. ${ }^{5}$ This implies that transfers are increasing in the amount of the investment $I$ and in the capability of the solidarity network, that is potential solidarity $\theta>0$ : more specifically, we assume that the amount of the actual transfer is given by $S=\theta e L$. Notice that $\theta$ measures potential solidarity which is different from the actual amount of the transfer $S$ : ex-post the solidarity transfer is zero either when the potential solidarity is null, $\theta=0$, or when the agent's effort is zero even though $\theta>0$.

The agent's problem is to choose consumption levels in period 1 and 2 in order to maximize the expected utility in (1) subject to the following income constraints

$$
\begin{aligned}
& C_{1} \leq(1-e) L \\
& C_{2} \leq p(R I-D)+(1-p) S \equiv p[\operatorname{Re} L-D]+(1-p) \theta e L
\end{aligned}
$$

and given the lender's participation constraint in (2). Substituting the two income constraints into the borrower's expected utility, it becomes a problem of intertemporal choice of consumption. ${ }^{6}$

Given loan size $L$ and debt face value $D$, the borrower chooses the share of the loan $e$ to consume in period 1 and as a consequence the amount to be invested in the productive project. The first order condition of the maximization problem is:

$$
\frac{u^{\prime}\left(C_{1}\right)}{u^{\prime}\left(C_{2}\right)}=\beta \alpha(\theta)
$$

where $\alpha(\theta) \equiv p R+(1-p) \theta>1$ is an increasing function of potential solidarity. There are two countervailing effects of a larger potential solidarity on the effort choice: on one hand a larger $\theta$ increases the net present value of each unit

\footnotetext{
${ }^{5}$ Solidarity tranfers are not observed by the MFIs hence cannot be claimed as part of the repayment of $D$.

${ }^{6}$ The problem is similar to setting savings (here, the effort) in the problem of intertemporal consumption. However here the effort is non-observable and hence there is a potential moral hazard problem.
} 
invested in production by providing an extra income in case of default $(1-p) \theta$; on the other hand, it increases the marginal utility of future consumption, since $C_{2}=\alpha(\theta) e L-p D$ increases with $\theta$, and in order to smooth consumption between the two periods, first period consumption must increase thus reducing the effort spent in the productive investment. The balance between these two contrasting effects decides the sign of the impact of solidarity on productive investment.

The optimal level of effort can be explicitly derived when substituting a specific utility function. Let us assume a constant relative risk aversion (CRRA) utility function ${ }^{7}$ in each period:

$$
u(C)=\left\{\begin{array}{cc}
\frac{C^{1-\gamma}}{1-\gamma} & \text { if } \gamma \neq 1 \\
\ln C & \text { if } \gamma=1
\end{array}\right.
$$

The marginal utility is either $u^{\prime}(C)=C^{-\gamma}$ for $\gamma \neq 1$ or it can be $u^{\prime}(C)=\frac{1}{C}$ when $\gamma=1$. After substituting the face value $D$ from a binding ${ }^{8}$ condition (2) into (5), the optimal effort is given by:

$$
e^{*}(\theta)=\frac{1+[\alpha(\theta) \beta]^{1 / \gamma}}{\alpha(\theta)+[\alpha(\theta) \beta]^{1 / \gamma}}
$$

The optimal effort is positive and smaller than 1 given that $p R>1$. We are interested in analyzing the impact of peer solidarity on the amount invested in the productive project.

Proposition 1 The positive effect of a greater potential peer solidarity on the share of the loan invested in the productive project increases the smaller is $\gamma$ and the greater is $R$ and $\beta$.

Proof. The derivative of the optimal effort $e^{*}$ in (6) with respect to the parameter measuring potential solidarity $\theta$ is

$$
\frac{d e^{*}}{d \theta}=\frac{\alpha^{\prime}(\theta)}{\gamma\left\{\alpha+[\alpha \beta]^{1 / \gamma}\right\}^{2}}\left\{[\alpha \beta]^{1 / \gamma}\left(\frac{\alpha-1}{\alpha}\right)-\gamma\left[(\alpha \beta)^{1 / \gamma}+1\right]\right\}
$$

\footnotetext{
${ }^{7}$ The CRRA function is general enough to encompass the interesting cases of linear, quadratic and logarithmic utility functions and at the same time to let enough flexibility to vary the degree of risk aversion of borrowers.

${ }^{8}$ We assume that competition drives MFIs to break even (Armendariz and Morduch, 2003, p. 139).
} 
where we have substituted $\alpha(\theta)$ with $\alpha$ whenever possible. The sign of the derivative depends upon the sign of the term inside the brackets, since the first factor of the product is always positive. The term in brackets is positive whenever

$$
\left(\frac{\alpha-1}{\alpha}\right) \geq \gamma\left[1+\frac{1}{(\alpha \beta)^{1 / \gamma}}\right]
$$

that is for small enough values of $\gamma$ (low degree of risk aversion) or for high enough values of $\alpha$ (marginal revenue of effort in the productive investment) or $\beta$ (low preference for present consumption). In case of $\gamma=1$ (logarithmic utility function) the sign is negative, but it may change as $\gamma$ becomes close to zero.

Let us analyze the effect of potential solidarity on the investment effort level within a numerical simulation where we let the degree of risk aversion and the intertemporal preference rate to vary.

On the one hand, the less risk averse is the borrower, the more she values a marginal increase in the present value of future investment and the smaller is her incentive to smooth consumption, thus increasing the effort in the productive investment. When we introduce some degree of risk aversion in borrower's preferences, the positive effect of solidarity diminishes since the higher net present value is also accompanied by a greater risk in the choice of delaying current consumption. In the following two Figures the parameters of the model are set to $R=2.5$ and $p=0.5 .^{9}$ In Figure 1 we plot the function $e^{*}(\theta)$ for different values of $\gamma$ : it shows a positive effect of potential solidarity the smaller the value of $\gamma$ (smaller degree of risk aversion).

\footnotetext{
${ }^{9}$ The only constraint on these parameters is $p R>1$. It is possible to show that other reasonable values of the two parameters provide similar behaviour for $e^{*}$ as function of $\theta$.
} 


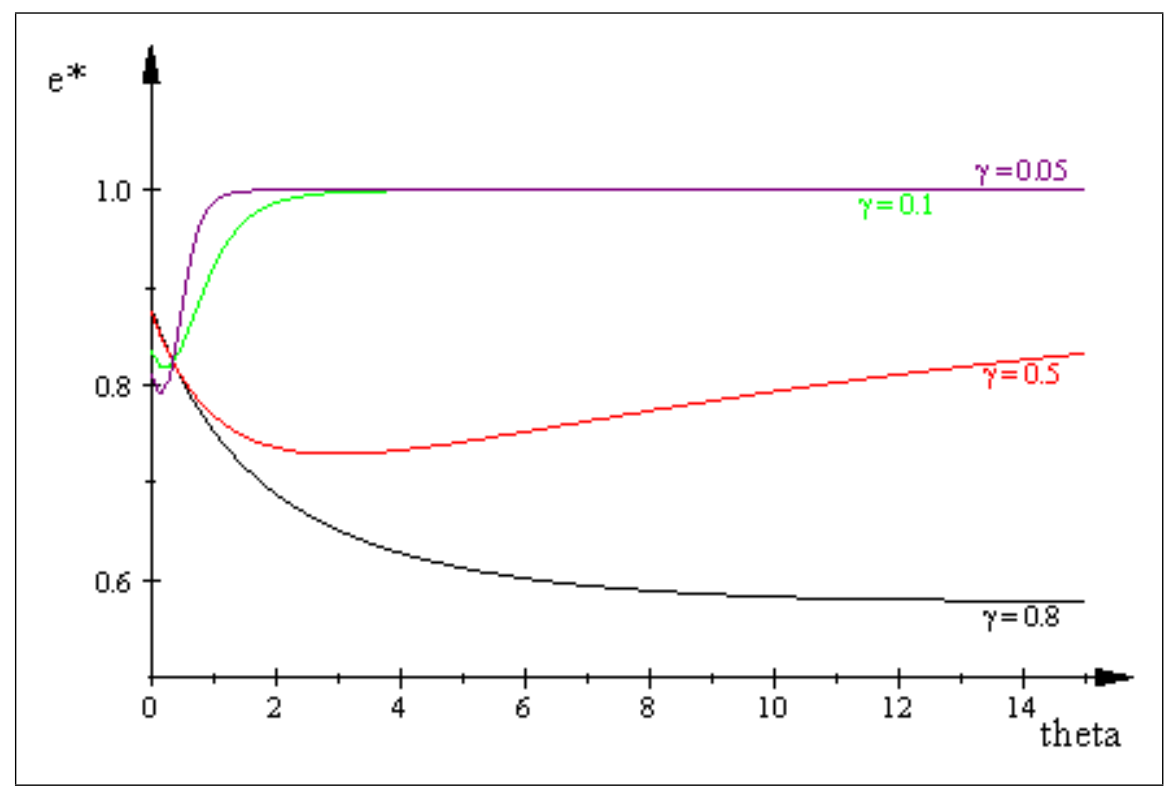

Figure 1

On the other hand, for a given degree of risk aversion $\gamma$, the larger the marginal revenue of future investment represented for instance by an increase in $\beta$ (although similar results may be obtained by an increase in $R$ or in $p$ ) and the greater is the incentive to exert effort in the productive investment. Figure 2 represents the function $e^{*}(\theta)$ for different values of $\beta$ and shows a positive effect of potential solidarity the larger the value of $\beta$ (greater weight to future consumption). 


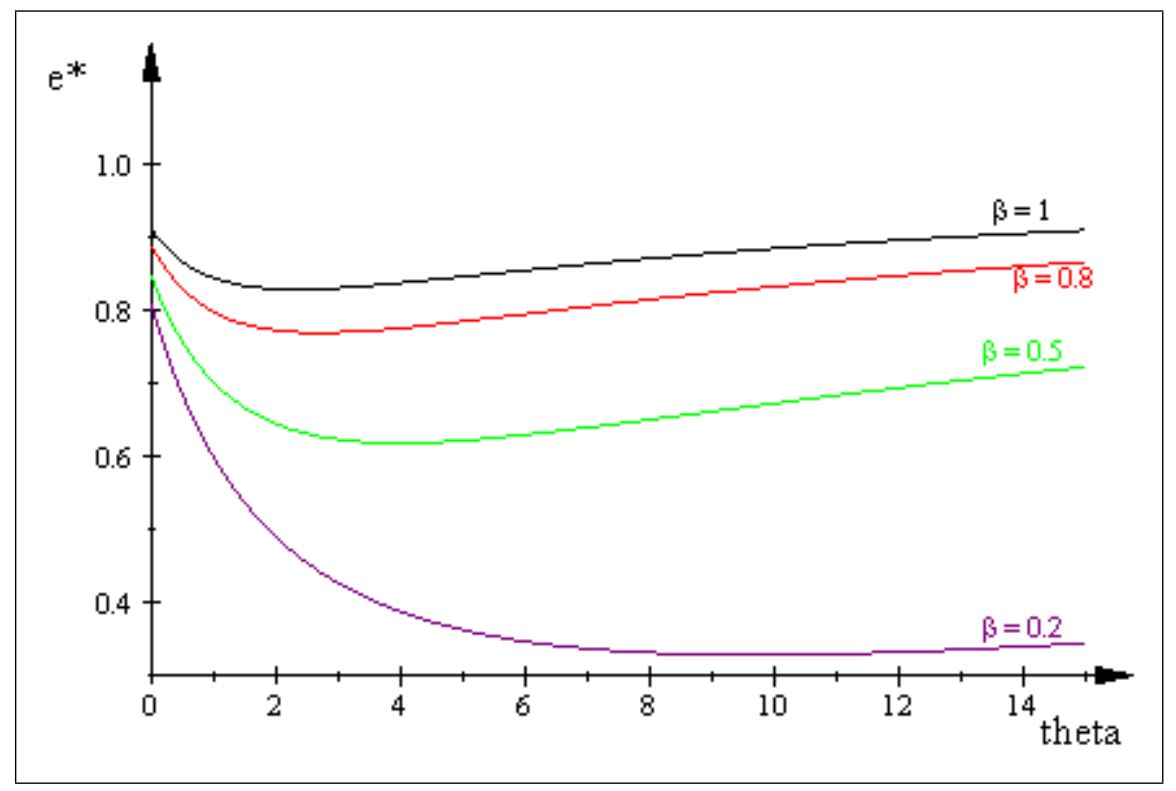

Figure 2

Given that our theoretical model predicts opposite effects of solidarity on productive investments depending on the attitude towards risk and intertemporal substitutability, we search for an empirical answer to this question. We measure the effect of solidarity on actual data in the context of less developed countries where MFIs programs are designed to facilitate access to banking for individuals lacking collateral. In what follows we test the predictions of our theoretical model on a sample of borrowers enrolled in micro-finance programs in Bangladesh.

\section{$3 \quad$ Data and Empirical Model}

Our sample is obtained from a survey of the Bangladesh Institute of Development Studies at the World Bank and consists of information on borrowers who joined microfinance programs in rural Bangladeshi villages between 1991 and $1992 .^{10}$

\footnotetext{
${ }^{10}$ Although the survey consists of three rounds, we concentrate on the first round (November-February), since relevant information for our objective is missing in the remaining two.
} 
We have information on participants to microfinance programs drawn from a larger group of households ${ }^{11}$ surveyed in three randomly selected villages from 29 districts (thanas). In 24 of these districts, at least one of the existent microcredit programs (Grameen, Bangladesh Rural Advanced Committee or Bangladesh Rural Development Board) had been in operation for at least three years. Overall 20 households were surveyed in each village for a total of 816 observations pertaining to MFI's customers.

We concentrate on borrowers enrolled in homogeneous lending programs in order to be able to compare them under different respects. In particular, for all households financed by the three MFIs mentioned above: a) the interest rate accorded is constant (16 percent at the time of the survey); b) loans are not collateralized. Other lenders (banks and informal lenders) offer loans at different conditions depending upon borrowers' characteristics.

Our proxy for the investment effort $e$ is a dummy variable which takes value 1 when the household declares ex-post in the survey that the loan has been used for productive purposes (either farming or other self-employed activities), 0 otherwise. According to the descriptive statistics in Table 1 it turns out that 83 percent of the households in the survey have invested the loan in productive activities, while the remaining share used it for personal purposes (e.g. dowries, food, and medical expenses).

In our context, the investment effort should not be explained by a variable capturing the actual amount of solidarity transfers (outcome of the solidarity ex-post), while instead by potential peer solidarity (measure of the ex-ante capability of the peers). According to the model, in fact, ex-post transfers are rewarded on the basis of actual effort, and may be related to its non-observable determinants, such as borrowers' ability. This may undermine the possibility of correctly identifying a causal effect of solidarity on effort itself.

A candidate measure of potential peer solidarity that might affect investment decisions is the number of close relatives (parents and siblings of the household

\footnotetext{
${ }^{11}$ The original sample includes non-borrowers and households borrowing from other credit sources (banks, informal lenders) for a total of 1,798 households.
} 
head and spouse) owning land. This variable captures the degree of peer solidarity ( $\theta$ in the model), that is the maximum possible solidarity of the network of relatives. We use the number of relatives owning land since, as widely recognized in the literature, land is one of the best and exogenous measure of wealth - at least for poor borrowers - in the areas where the survey has been conducted (see for example Pitt and Khandker, 1998). In the dataset the number of parents and siblings owning land is on average 3.6, with a maximum of 20 .

We also account for the presence of actual transfers received in both cash and food, which may affect the choice of investing by relaxing the household's budget constraint. Actual transfers, however, turn to be relatively small in value (148 taka of cash and 5 taka in food on average $)^{12}$ and relatively volatile across households.

An important control variable in this analysis is households' own wealth. In fact, although borrowers in the sample belong to the lowest percentile of the welfare distribution, they could slightly differ in terms of cash endowments, a fact that may affect both liquidity constraints and the attitude towards risk. Therefore, we consider households' land to capture wealth. In the dataset, households own relatively small plots of land (0.41 acres on average) a figure which well reflects MFIs' policy approach towards poverty.

Information about the type of activity of the head of the family is important in order to capture possible differences in the expected return of the project $(p R$ in the model). Due to floods, droughts and adverse climate conditions in general, farming activity is indeed likely to be associated with a higher variance of returns and difficulties to commit to regular installments (see for example Caldwell et al., 1986) which may end up influencing investment choices, especially in the case of risk-averse borrowers. In order to control for these features we add a dummy indicating whether the head of the family is a farmer. In particular, farming is the main activity of the household head for 68 percent of the cases in the sample.

Another characteristic related to the expected return of the project is the

\footnotetext{
${ }^{12}$ At the moment we write, one euro is worth $\mathbf{1 0 7 . 7 4}$ taka.
} 
status of self-employed workers versus employees, since it is reasonable to think that the former requires a higher expected return to offset the greater risk incurred. According to our data, 57 percent of household heads are self-employed, while all others are employees.

We also introduce several variables in order to capture the intertemporal preference rate, $\beta$, such as age of the household head and spouse, their education, number of persons composing the household, and number of children (either living inside the household or elsewhere). The latter, in particular, seems a good proxy for the weight accorded to future consumption. The average age of the household head and his/her spouse is 35 years, meanwhile they attended school for approximately 2 years. Households have 5 members on average, the head of the family and spouse have 2 parents alive (within 4), 10 close relatives (mostly siblings) and 6 children.

As a measure of risk aversion, $\gamma$, we use a dummy taking value 1 when the household head is male. In fact, it is argued that gender may reflect a different attitude towards risk and investment (see for example Schubert et al., 1999 for a discussion). In our dataset, in particular, the household head is male in 94 percent of the cases.

Furthermore, we control for exogenous shocks occurred to household members. In fact, funds might be subtracted from productive uses in case household's members require medical treatment. Even in case of marriage it is possible that productive projects are foregone in order to provide dowries. In the dataset the number of household members who have been hit by some injury is 1 on average, with a maximum of 7 , while 1.4 percent of the households declared that they provided their daughters with a dowry ${ }^{13}$.

We control also for the presence of alternative sources of credit. Similarly to heterogeneity in wealth, other sources of credit may account for differences in the share of funds invested in production. In our context 5 percent of the

\footnotetext{
${ }^{13}$ The figure reporting the percentage of households providing dowries looks particularly low. Underreporting, however, might be due to the fear of being dropped from MF programs since the latter often provide recommendations against the use of funds for such purposes.
} 
households have obtained credit from informal moneylenders (such as input suppliers, merchants, landlords, relatives ${ }^{14}$ and friends), while 2 percent from banks. The average loan size accorded by informal lenders amounts to 3,775 taka (approximately 35 euro) while it is 3,595 taka (approximately 33 euro) ${ }^{15}$ for bank lending, with greater variability. Loans from MFIs are on average 7,546 taka (approximately 70 euro).

Finally, borrowers are asked how much would they be willing to borrow again in the future. We consider their answers as a measure of their opportunity cost of not being granted credit in the future, hence a measure of how severe is for them the threat of non-refinancing. Basically, the larger the amount declared, the higher is the cost of the threat for them. On average, the desired amount is double compared to the current loan.

We start by setting the following regression:

$$
z_{i j}=\alpha_{0} \theta_{i j}+\alpha_{1} h_{i j}+\alpha_{2} A_{i j}+\mu_{j}+\epsilon_{i j}
$$

where $i$ identifies the household and $j$ the village in which the household lives. The dependent variable $z_{i j}$, ranging on real values from $-\infty$ to $+\infty$, is a latent variable related to the effort that household $i$ wishes to devote to a given productive project (i.e. the share of funds invested) conditional on potential solidarity proxied by the number of relatives owning land $\theta_{i j}$, on household's wealth measured by land $h_{i j}$ and a set of controls $A_{i j}$. Finally, $\mu_{j}$ are village specific-effects, while $\epsilon_{i j}$ is an i.i.d. error with conditional mean $E\left(\epsilon_{i j} \mid \theta_{i j}, h_{i j}, A_{i j}, \mu_{j}\right)=0$.

Denote the variable expressing effort with $y_{i j}$ and let $y_{i j}=1$ when a positive answer is associated to the question whether the amount borrowed has been used for productive purposes, and zero otherwise $\left(y_{i j}=0\right)$. We assume that the answer is related to the latent variable capturing the propensity to invest, namely that $y_{i j}=1$ if $z_{i j}>0$ and $y_{i j}=0$ if $z_{i j} \leq 0$.

\footnotetext{
${ }^{14}$ Note that these are indeed loans from relatives, but in contrast with solidarity transfers, they must be refunded at a specified interest rate.

${ }^{15}$ Normally, the amount of a bank loan is considerably larger (see Dalla Pellegrina, 2011). However, it dramatically drops when households contemporaneously borrow from banks and MFIs.
} 
We use a probit model to estimate the probability over the observable variable, that is $\operatorname{Pr}\left\{y_{i j}=1 \mid \theta_{i j}, h_{i j}, A_{i j}, \mu_{j}\right\}$.

\section{Results}

The results of the several regression models are summarized in Table 2 in the Appendix.

Estimates provide evidence that a higher number of relatives owning land, i.e. the measure of potential peer solidarity, increases the probability that the borrower uses funds for productive activities. This measure of potential solidarity is always significant and robust to alternative specifications. In particular, the estimated marginal effect suggests that owning one more relative with land increases the probability of investing in productive projects by 1.4 percent (simple mean across different specifications). Although semi-elasticities may result relatively small due to the high share of households investing in productive activities (83 per cent, see Table 1) this is an important figure considering the width of the network of relatives existing in rural areas of poor countries. In our dataset, for example, the observed average number of relatives with land is 3.6. Compared to households with no landed relatives, this family has slightly more than five percent higher probability of investing the loan in productive activities.

In each of the different regressions we account for household characteristics that may affect the choice of diverting loans towards current consumption rather than investing, such as the average age of the household head and his spouse, the average number of years of education, gender of the household head, number of household members and the household network size measured by the number of relatives who are alive. In the latter case we separate parents and siblings from the number of children, since borrowers' offspring may better reflect their intertemporal preference rate. Moreover, we include the dummies for farming and for self-employed activities, while leaving employees as a residual class. 
As for differences across specifications of the estimated model, in column (1) in Table 2 we neither control for alternative sources of lending nor for possible shocks affecting household welfare, actual transfers, and importance of future financing. In column (2) we control for the former by including a dummy which takes value 1 when the household also borrowed from informal lenders or banks, separating the two alternative sources. In column (3) we replace the previous dummies with a continuous variable measuring the amount of the loans obtained from alternative sources. In column (4) we add variables capturing shocks, such as diseases of a household's member or the payment of a dowry. In column (5) we account for incentives provided by the threat to foreclose access to future lending as measured by the desired amount of future loans, and for the presence of actual transfers in both cash and food.

Throughout all specifications in Table 2 the proxy for households' own wealth - i.e. land ownership - is significant and exhibits a positive sign. This is somehow expected: households without liquidity constraints are less likely to divert borrowed funds for immediate consumption purposes, thus investing more in production.

The relationship between some other household characteristics and investment effort is also particularly interesting. For example, younger people seem more inclined to devote funds to productive purposes, a fact that should reflect the higher weight they put on future consumption (higher $\beta$ ), which is in line with our theoretical analysis. Also the sign of the coefficient associated to the number of children, although less significant, provides similar evidence.

The result for education is somehow surprising, since more educated households tend to invest less. One possibility is that highly educated workers are also more productive, and thus may invest less to achieve the same output of less productive individuals. An alternative explanation could be that more educated workers are also richer (the correlation with household land is 30 per cent, see Table A1) and deliberately borrow for non-productive purposes, being confident that they can repay the loan through financial resources other than income on investment. 
Male household heads seem more prone to invest in production compared to females. We may interpret this result with males having a different degree of risk aversion compared to females (low $\gamma$ for males compared to females). In particular, women may be likely to save more resources for child raring and education (Jackson, 1996; Pitt and Khandker, 1998; Kritikos and Vigenina, 2005) so that they turn out investing less in production. ${ }^{16}$

Being self-employed increases the probability of investing. This result could be affected by endogeneity, however, since one of the objectives of MFIs is to promote self-employment. On the other hand, the result that farmers tend to invest less represents interesting evidence, since it might reflect the fact that agriculture returns a lower expected value per unit invested (smaller $R$ ). Even this result however could be affected by endogeneity due to the policy of MFIs to target manufacturing.

Our measures of shocks are also significant and with the expected - negative - sign, suggesting that injuries and dowries are both likely to divert funds from productive purposes (column (4)). Notice however that their correlation with the dependent variable is not negative.

As far as the alternative sources of lending are concerned (see columns (2)(4)), it is interesting to note that their presence and amount reduce the probability of investing in production. This result is stronger for informal lending and could be due to the high correlation of informal lending with non measurable features such as negative shocks - i.e. other than illness and dowries - which may affect investment.

The coefficient associated to desired future loans is not significant (column (5)) suggesting that the threat of non refinancing is weak. However one should be careful in interpreting this evidence, since the variable capturing the amount of desired future loan is highly correlated with the actual amount of the loan (see Table A1 in the Appendix).

\footnotetext{
${ }^{16}$ However, it is worth observing that there is not a significant number of women who are household heads in the data, so that such a result may be driven by the scarcity of cases.
} 
Column (6) reports estimates when excluding relatives with land. This is important in order to verify whether the observed effect on invested funds depends upon the simple size of a solidarity network (number of relatives alive), regardless of its financial capability. In our case we can be reasonably confident that what matters for the propensity to invest is the financial strenght of the network and not the simple size of the network, since parameters associated to the latter are not affected (do not become significant) when the number of relatives with land is removed from the set of explanatory variables.

Finally, we control for the effect of MFIs' loan size on the use of loans for production for robustness check (Table 3). Comparing Tables 2 and 3, one can see as a robustness check that the previous results on the probability of investing in productive activities are not affected by the presence of the loan size in the regression. Apart from this fact, interesting evidence is provided by the sign and significance of the parameter associated to MFIs' loans. This confirms the positive effect of microfinance on investment when compared to other sources of lending, as already documented by Dalla Pellegrina (2011).

\section{Concluding remarks}

In this paper we test whether peer solidarity enhances productive investment in a context of asymmetric information between borrowers and lenders, when borrowers may divert loans for current consumption and have no endowments to be used as collateral, as it is the case for less developed countries where MFIs operate.

In this framework, the impact of greater peer solidarity may be in principle ambiguous: on the one hand, greater solidarity increases the expected return of the investment by providing a buffer in case of default, hence making investment more appealing. On the other hand, consumption smoothing may require to increase the value of current consumption, hence reducing the propensity to invest.

We test the predictions of the model using data from a survey of the World 
Bank on a sample of households participating to microfinance programs in Bangladesh during the period 1991-1992. Empirical findings suggest that the propensity to use the loan for productive activities is enhanced by the potential solidarity of the network of relatives. Results are robust to different specifications of the model.

In conclusion, from the MFIs point of view it is important to consider repayment enforcement mechanisms that rely not only on group joint liability (and related sanctions imposed by same-group members) but also on borrowers' potential solidarity network. Our paper shows evidence that peer solidarity may be an instrument to enforce good behavior, regardless of the fact that the structure of loans is group-based or individually-based. Given the current attitude of several MFIs to shift towards individual lending, the role of solidarity may thus acquire importance in the next future compared to other group-based loan enforcement mechanisms. 


\section{References}

[1] Armendáriz de Aghion B., and J. Morduch, 2000, Microfinance Beyond Group Lending, Economics of Transition, 8 (2), 401-420.

[2] Armendáriz de Aghion B., and J. Morduch, 2003, Microfinance: Where Do We Stand? in Financial Development and Economic Growth: Explaining the Links, ed. by C. Goodhart, Macmillan/Palgrave.

[3] Armendáriz de Aghion B., and J. Morduch, 2005, The Economics of Microfinance, MIT Press, Cambridge MA.

[4] Barua D., and A. Dowla, 2006, The poor always pay back: the Grameen II story, Bloomfield, CT: Kumarian Press, Inc.

[5] Basu A., R. Blavy, and M. Yulek, 2004, Microfinance in Africa: Experience and Lessons from selected African Countries, IMF Working Paper 04/174.

[6] Besley T., and S. Coate, 1995, Group Lending, Repayment Incentives and Social Collateral, Journal of Development Economics, 46 (1), 1-18.

[7] Caldwell J. C., P. H. Reddy, and P. Caldwell, 1986, Periodic High Risk as a Cause of Fertility Decline in a Changing Rural Environment: Survival Strategies in the 1980-1983 South Indian Drought, Economic Development and Cultural Change, 34 (4), 677-701.

[8] Dalla Pellegrina L., 2011, Microfinance and Investment: a Comparison with Bank and Informal Lending, World Development, 39 (6), 882-897.

[9] Ghatak M., 1999, Group lending, local information and peer selection, Journal of Development Economics, 60, 27-50.

[10] Ghatak M., 2000, Screening by the Company You Keep: Joint Liability Lending and the Peer Selection Effect, The Economic Journal, 110 (465), 601-631.

[11] Ghosh P., D. Mokherjee, and D. Ray, 2000, Credit Rationing in Developing Countries: An Overview of the Theory, in D. Mokherjee and D. Ray, Readings in the Theory of Economic Development, Blackwell Publishing Company.

[12] Giné X., P. Jakiela, D. S. Karlan, and J. Morduch, 2006, Microfinance Games, Yale University Economic Growth Center Discussion Paper No. 936.

[13] Hermes N., R. Lensink, H. T., and Mehrteab, 2005, Peer Monitoring, Social Ties and Moral Hazard in Group Lending Programs: Evidence from Eritrea, World Development, 33 (1), 149-169.

[14] Jackson C., 1996, Rescuing Gender From the Poverty Trap, World Development, 24 (3), 489-504. 
[15] Karlan D. S., 2005, Using Experimental Economics to Measure Social Capital and Predict Financial Decisions, American Economic Review, 95(5), 1688-1699.

[16] Kritikos A. S., and D. Vigenina, 2005, Key Factors of Joint-Liability Loan Contracts. An Empirical Analysis, KYKLOS, 58 (2), 213-238.

[17] Menon N., 2004, Consumption Smoothing in Micro-Credit Programs, Development and Comp Systems 0403005, EconWPA.

[18] Nissanke M., 2002, Donors' Support for Microcredit as Social Enterprise. A Critical Reappraisal, Discussion Paper No. 127 United Nations University, Helsinki.

[19] Pitt M. M., and S. Khandker, 1998, The Impact of Group-Based Credit Programs on Poor Households in Bangladesh: Does the Gender of Participants Matter?, Journal of Political Economy,106 (5), 958-996.

[20] Wenner M. D., 1995, Group Credit: A Means to Improve Information Transfer and Loan Repayment Performance, Journal of Development Studies, 32 (2), 264-81.

[21] Wydick B., 1999, Can Social Cohesion be Harnessed to Repair Market Failures? Evidence from Group Lending in Guatemala, The Economic Journal, 109 (457), 463 - 475.

[22] Schubert, R., Brown, M., Gysler, M., \& Brachinger, H. W., 1999, Gender and Economic Transactions. Financial Decision-Making: Are Women Really More Risk-Averse?. The American Economic Review, 89 (2), 381-385.

[23] Stiglitz J., 1990, Peer Monitoring and Credit Markets, World Bank Economic Review 4 (3), 351-66. 
Table 1 - Descriptive statistics

\begin{tabular}{|c|c|c|c|c|c|c|}
\hline Variable & & Obs & Mean & $\begin{array}{l}\text { Std. } \\
\text { Dev. }\end{array}$ & Min & $\operatorname{Max}$ \\
\hline $\begin{array}{l}\text { Productive use of } \\
\text { loan }\end{array}$ & $\begin{array}{l}=1 \text { if loan has been used for productive purposes } \\
\text { (farming or other self-employed activities), } 0 \\
\text { otherwise }\end{array}$ & 816 & 0.83 & 0.36 & 0 & 1 \\
\hline $\begin{array}{l}\text { Relatives own } \\
\text { land }\end{array}$ & number of relatives owning land & 816 & 3.60 & 3.95 & 0 & 20 \\
\hline Land & acres of land owned by the household & 816 & 0.40 & 0.91 & 0 & 13.65 \\
\hline Age & average age of household head and spouse & 816 & 34.68 & 11.35 & 8 & 72.5 \\
\hline Education & $\begin{array}{l}\text { average years of education of household head and } \\
\text { spouse }\end{array}$ & 816 & 2.04 & 2.50 & 0 & 13 \\
\hline $\begin{array}{l}\text { Household head is } \\
\text { male }\end{array}$ & $=1$ if the household head is male, 0 otherwise & 816 & 0.94 & 0.23 & 0 & 1 \\
\hline $\begin{array}{l}\text { Household } \\
\text { members }\end{array}$ & number of individuals living in the household & 816 & 5.25 & 1.98 & 1 & 17 \\
\hline Relatives alive & $\begin{array}{l}\text { total number of relatives owned by household head } \\
\text { and spouse }\end{array}$ & 816 & 10.19 & 4.61 & 0 & 28 \\
\hline Children alive & $\begin{array}{l}\text { number of daughters and sons living either inside } \\
\text { or outside the household }\end{array}$ & 816 & 6.37 & 4.17 & 0 & 24 \\
\hline Farming & $=1$ if the household head is a farmer, 0 otherwise & 816 & 0.68 & 0.46 & 0 & 1 \\
\hline $\begin{array}{l}\text { Other self- } \\
\text { employed }\end{array}$ & $\begin{array}{l}=1 \text { if the household head is a self-employed } \\
\text { worker, } 0 \text { otherwise }\end{array}$ & 816 & 0.57 & 0.49 & 0 & 1 \\
\hline Injury & $\begin{array}{l}\text { number of household members who have been ill } \\
\text { during the last year }\end{array}$ & 816 & 1.05 & 1.13 & 0 & 7 \\
\hline Dowry & $\begin{array}{l}1 \text { if the household has paid a dowry during the last } \\
\text { year, } 0 \text { otherwise }\end{array}$ & 816 & 0.01 & 0.12 & 0 & 1 \\
\hline Informal loan & $\begin{array}{l}=1 \text { if the household has received credit by informal } \\
\text { lenders, } 0 \text { otherwise }\end{array}$ & 816 & 0.05 & 0.23 & 0 & 1 \\
\hline Bank loan & $=1$ if the household has received credit by banks & 816 & 0.02 & 0.15 & 0 & 1 \\
\hline $\begin{array}{l}\text { Informal loan } \\
\text { amount }\end{array}$ & $\begin{array}{l}\text { amount of credit (in taka) accorded by informal } \\
\text { lenders }\end{array}$ & 40 & 3,775 & 3,986 & 1,000 & 17,000 \\
\hline Bank loan amount & $\begin{array}{l}\text { amount of credit (in taka) accorded by informal } \\
\text { lenders }\end{array}$ & 21 & 3,595 & 2,154 & 1,000 & 9,500 \\
\hline MF loan amount & $\begin{array}{l}\text { amount of credit (in taka) accorded by MFI } \\
\text { programs }\end{array}$ & 816 & 7,546 & 6,827 & 1,000 & 54,000 \\
\hline Size future loan & $\begin{array}{l}\text { desired amount of the next loan (in taka) by MFI } \\
\text { programs }\end{array}$ & 816 & 14,293 & 16,843 & 1,000 & 200,000 \\
\hline Transfers: cash & $\begin{array}{l}\text { amount of transfers (in taka) in cash accrued to the } \\
\text { household }\end{array}$ & 816 & 147.59 & 1,465 & 0 & 33,000 \\
\hline Transfers: food & $\begin{array}{l}\text { amount of transfers (in taka) in food accrued to the } \\
\text { household }\end{array}$ & 816 & 5.08 & 80.07 & 0 & 2,000 \\
\hline
\end{tabular}


Table 2- Effect of solidarity on the use of MFIs loans

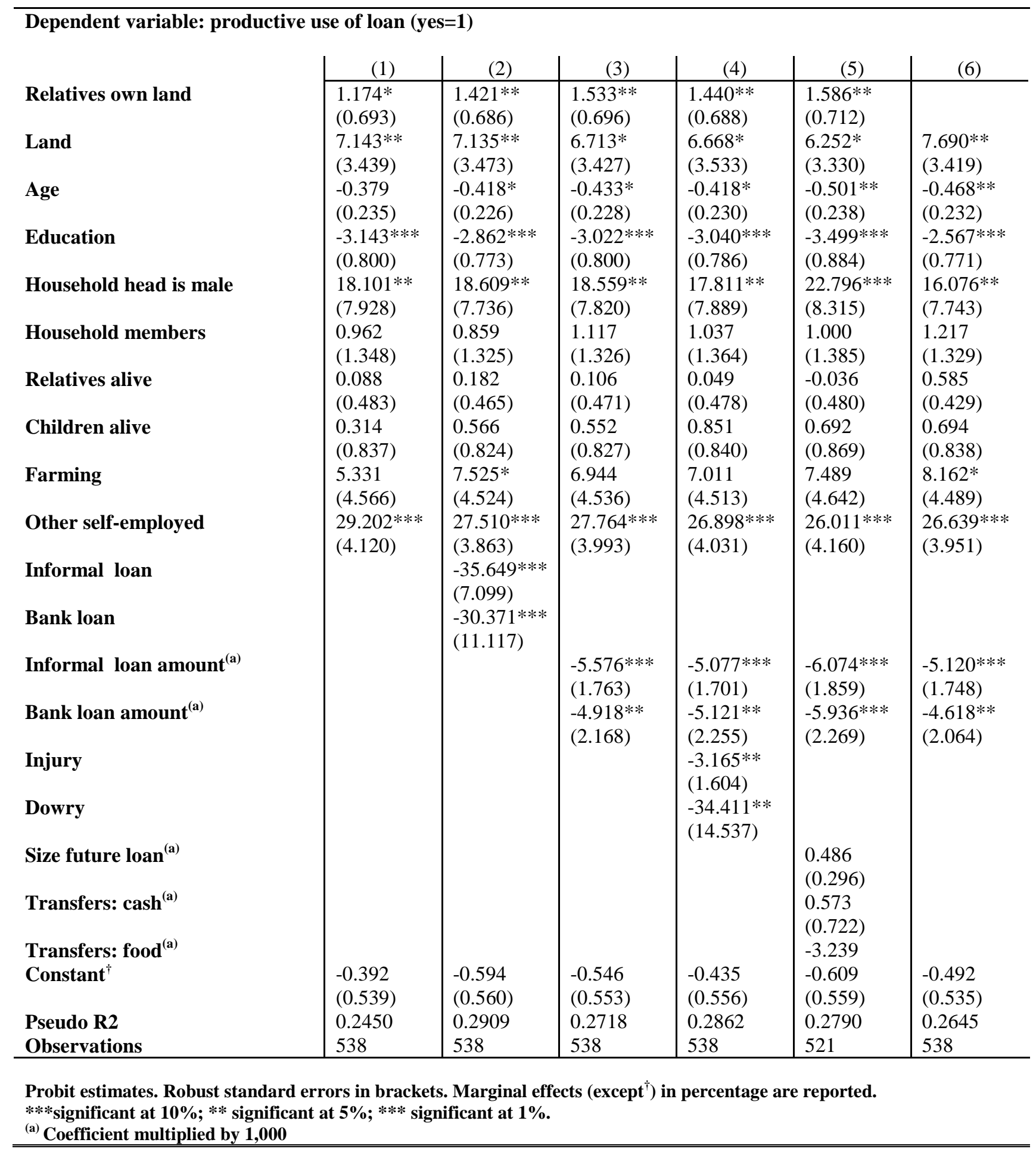


Table 3 - Effect of solidarity on the use of MFIs loans Regressions including loan amount

\begin{tabular}{|c|c|c|c|c|c|c|}
\hline \multicolumn{7}{|c|}{ Dependent variable: productive use of loan (yes=1) } \\
\hline & (1) & (2) & (3) & (4) & (5) & (6) \\
\hline Relatives own land & $\begin{array}{l}1.222 * \\
(0.657)\end{array}$ & $\begin{array}{l}1.462 * * \\
(0.635)\end{array}$ & $\begin{array}{l}1.618^{* * *} \\
(0.659)\end{array}$ & $\begin{array}{l}1.495^{* * *} \\
(0.639)\end{array}$ & $\begin{array}{l}1.764^{* * *} \\
(0.697)\end{array}$ & \\
\hline Land & $\begin{array}{l}6.699 * * \\
(3.252)\end{array}$ & $\begin{array}{l}6.528 * * \\
(3.156)\end{array}$ & $\begin{array}{l}6.101^{*} \\
(3.140)\end{array}$ & $\begin{array}{l}5.889^{*} \\
(3.106)\end{array}$ & $\begin{array}{l}6.399 * * \\
(3.243)\end{array}$ & $\begin{array}{l}7.095 * * \\
(3.182)\end{array}$ \\
\hline MF loan amount & $\begin{array}{l}2.140 * * * \\
(0.578)\end{array}$ & $\begin{array}{l}2.215^{* * * *} \\
(0.570)\end{array}$ & $\begin{array}{l}2.275 * * * \\
(0.573)\end{array}$ & $\begin{array}{l}2.456 * * * \\
(0.571)\end{array}$ & $\begin{array}{l}2.322 * * * \\
(0.677)\end{array}$ & $\begin{array}{l}2.219 * * * \\
(0.585)\end{array}$ \\
\hline Age & $\begin{array}{l}-0.485^{* *} \\
(0.246)\end{array}$ & $\begin{array}{l}-0.522 * * \\
(0.237)\end{array}$ & $\begin{array}{l}-0.543 * * \\
(0.239)\end{array}$ & $\begin{array}{l}-0.549 * * \\
(0.239)\end{array}$ & $\begin{array}{l}-0.595 * * \\
(0.250)\end{array}$ & $\begin{array}{l}-0.578 * * \\
(0.242)\end{array}$ \\
\hline Education & $\begin{array}{l}-3.235^{* * *} \\
(0.767)\end{array}$ & $\begin{array}{l}-3.003 * * * \\
(0.741)\end{array}$ & $\begin{array}{l}-3.128 * * * \\
(0.771)\end{array}$ & $\begin{array}{l}-3.117 * * * \\
(0.749)\end{array}$ & $\begin{array}{l}-3.552 * * * \\
(0.863)\end{array}$ & $\begin{array}{l}-2.636^{* * *} \\
(0.740)\end{array}$ \\
\hline Household head is male & $\begin{array}{l}18.695 * * \\
(7.565)\end{array}$ & $\begin{array}{l}19.153^{* * * *} \\
(7.233)\end{array}$ & $\begin{array}{l}19.171 * * * \\
(7.359)\end{array}$ & $\begin{array}{l}18.151 * * \\
(7.325)\end{array}$ & $\begin{array}{l}23.371 \text { *** } \\
(7.834)\end{array}$ & $\begin{array}{l}16.310^{* *} \\
(7.293)\end{array}$ \\
\hline Household members & $\begin{array}{l}0.949 \\
(1.338)\end{array}$ & $\begin{array}{l}0.820 \\
(1.311)\end{array}$ & $\begin{array}{l}1.085 \\
(1.312)\end{array}$ & $\begin{array}{l}0.914 \\
(1.328)\end{array}$ & $\begin{array}{l}0.875 \\
(1.387)\end{array}$ & $\begin{array}{l}1.190 \\
(1.312)\end{array}$ \\
\hline Relatives alive & $\begin{array}{l}0.062 \\
(0.472)\end{array}$ & $\begin{array}{l}0.144 \\
(0.446)\end{array}$ & $\begin{array}{l}0.063 \\
(0.454)\end{array}$ & $\begin{array}{l}0.041 \\
(0.455)\end{array}$ & $\begin{array}{l}0.048 \\
(0.472)\end{array}$ & $\begin{array}{l}0.565 \\
(0.414)\end{array}$ \\
\hline Children alive & $\begin{array}{l}0.490 \\
(0.854)\end{array}$ & $\begin{array}{l}0.755 \\
(0.833)\end{array}$ & $\begin{array}{l}0.758 \\
(0.837)\end{array}$ & $\begin{array}{l}1.184 \\
(0.838)\end{array}$ & $\begin{array}{l}0.888 \\
(0.882)\end{array}$ & $\begin{array}{l}0.914 \\
(0.849)\end{array}$ \\
\hline Farming & $\begin{array}{l}3.246 \\
(4.399)\end{array}$ & $\begin{array}{l}5.529 \\
(4.306)\end{array}$ & $\begin{array}{l}4.869 \\
(4.339)\end{array}$ & $\begin{array}{l}4.715 \\
(4.227)\end{array}$ & $\begin{array}{l}6.038 \\
(4.543)\end{array}$ & $\begin{array}{l}6.230 \\
(4.322)\end{array}$ \\
\hline Other self-employed & $\begin{array}{l}27.451 * * * \\
(4.034)\end{array}$ & $\begin{array}{l}25.581 * * * \\
(3.771)\end{array}$ & $\begin{array}{l}25.798 * * * \\
(3.901)\end{array}$ & $\begin{array}{l}24.548^{* * * *} \\
(3.915)\end{array}$ & $\begin{array}{l}26.234 * * * \\
(4.062)\end{array}$ & $\begin{array}{l}24.633 * * * \\
(3.846)\end{array}$ \\
\hline $\begin{array}{l}\text { Informal loan } \\
\text { Bank loan }\end{array}$ & & $\begin{array}{l}-35.233 * * * \\
(7.135) \\
-32.537 * * * \\
(10.657)\end{array}$ & & & & \\
\hline Informal loan amount ${ }^{(a)}$ & & & $\begin{array}{l}-5.630 * * * \\
(1.703)\end{array}$ & $\begin{array}{l}-5.074 * * * \\
(1.582)\end{array}$ & $\begin{array}{l}-5.802^{* * * *} \\
(1.787)\end{array}$ & $\begin{array}{l}-5.130 * * * \\
(1.691)\end{array}$ \\
\hline Bank loan amount $^{(a)}$ & & & $\begin{array}{l}-5.341 * * \\
(2.130)\end{array}$ & $\begin{array}{l}-5.329 * * \\
(2.401)\end{array}$ & $\begin{array}{l}-5.544 * * \\
(2.276)\end{array}$ & $\begin{array}{l}-4.962 * * \\
(2.072)\end{array}$ \\
\hline Injury & & & & & & \\
\hline Dowry & & & & $\begin{array}{l}-38.138 * * * \\
(14.247)\end{array}$ & & \\
\hline Size future loan ${ }^{(a)}$ & & & & & $\begin{array}{l}0.003 \\
(0.196)\end{array}$ & \\
\hline Transfers: $\operatorname{cash}^{(a)}$ & & & & & $\begin{array}{l}0.553 \\
(0.695)\end{array}$ & \\
\hline Transfers: food ${ }^{(a)}$ & & & & & -4.972 & \\
\hline Constant $^{\dagger}$ & $\begin{array}{l}-0.455 \\
(0.543)\end{array}$ & $\begin{array}{l}-0.680 \\
(0.569)\end{array}$ & $\begin{array}{l}-0.636 \\
(0.560)\end{array}$ & $\begin{array}{l}-0.521 \\
(0.566)\end{array}$ & $\begin{array}{l}-0.720 \\
(0.568)\end{array}$ & $\begin{array}{l}-0.561 \\
(0.542)\end{array}$ \\
\hline $\begin{array}{l}\text { Pseudo R2 } \\
\text { Observations }\end{array}$ & $\begin{array}{l}0.2683 \\
538\end{array}$ & $\begin{array}{l}0.3163 \\
538\end{array}$ & $\begin{array}{l}0.2978 \\
538\end{array}$ & $\begin{array}{l}0.3155 \\
538\end{array}$ & $\begin{array}{l}0.2970 \\
521\end{array}$ & $\begin{array}{l}0.2892 \\
538\end{array}$ \\
\hline
\end{tabular}

Probit estimates. Robust standard errors in brackets. Marginal effects (except $\left.{ }^{\dagger}\right)$ in percentage are reported. ***significant at $10 \%$; ** significant at $5 \%$; *** significant at $1 \%$.

(a) Coefficient multiplied by 1,000 
Table A1 - Correlation between variables

\begin{tabular}{|c|c|c|c|c|c|c|c|c|}
\hline & $\begin{array}{l}\text { Productive } \\
\text { use of } \\
\text { loan }\end{array}$ & Age & Education & $\begin{array}{l}\text { Household } \\
\text { head is } \\
\text { male }\end{array}$ & $\begin{array}{l}\text { Household } \\
\text { members }\end{array}$ & $\begin{array}{l}\text { Relatives } \\
\text { alive }\end{array}$ & $\begin{array}{l}\text { Children } \\
\text { alive }\end{array}$ & Farming \\
\hline Productive use of loan & 1 & & & & & & & \\
\hline Age & -0.0119 & 1 & & & & & & \\
\hline Education & -0.0346 & 0.0936 & 1 & & & & & \\
\hline Household head is male & 0.0802 & 0.2302 & 0.0753 & 1 & & & & \\
\hline Household members & 0.0595 & 0.4058 & 0.197 & 0.1572 & 1 & & & \\
\hline Relatives alive & 0.0391 & -0.2764 & 0.1022 & 0.207 & -0.1014 & 1 & & \\
\hline Children alive & 0.0262 & 0.6904 & 0.0924 & 0.0878 & 0.6651 & -0.1623 & 1 & \\
\hline Farming & 0.1105 & 0.1115 & 0.0894 & 0.1203 & 0.108 & 0.0812 & 0.1024 & 1 \\
\hline Other self-employed & 0.2245 & 0.0131 & -0.0138 & 0.0351 & 0.0771 & 0.008 & 0.0294 & -0.0172 \\
\hline Injury & 0.0238 & 0.0936 & 0.0505 & 0.0304 & 0.2033 & -0.0359 & 0.1584 & -0.0562 \\
\hline Dowry & -0.1675 & 0.1169 & -0.0102 & -0.0143 & 0.0254 & -0.0404 & 0.133 & -0.0048 \\
\hline Informal loan & -0.204 & 0.0276 & 0.1179 & 0.0314 & 0.0649 & 0.0527 & 0.0867 & 0.0026 \\
\hline Bank loan & 0.0294 & -0.0705 & 0.0019 & 0.0397 & -0.0364 & 0.067 & -0.0589 & 0.0436 \\
\hline Informal loan amount & -0.1516 & 0.0626 & 0.1291 & 0.0156 & 0.1035 & 0.0232 & 0.1455 & 0.0116 \\
\hline Bank loan amount & 0.0162 & -0.0492 & -0.0084 & 0.0342 & -0.0006 & 0.0562 & -0.0361 & 0.0549 \\
\hline MF loan amount & 0.1897 & 0.0994 & 0.0717 & 0.0192 & 0.1526 & -0.0057 & 0.0806 & 0.1055 \\
\hline Size future loan & 0.1167 & 0.1141 & 0.0761 & 0.0358 & 0.1697 & 0.0043 & 0.099 & 0.0489 \\
\hline Relatives own land & 0.0879 & 0.1089 & 0.2695 & 0.0379 & 0.22 & -0.0682 & 0.1259 & 0.2478 \\
\hline Land & 0.1191 & -0.0516 & 0.2954 & 0.0305 & 0.0821 & 0.3928 & 0.0275 & 0.2441 \\
\hline Transfers: cash & 0.0281 & -0.0175 & 0.0775 & -0.1812 & 0.1165 & -0.0085 & 0.0514 & -0.0041 \\
\hline Transfers: food & -0.0137 & -0.023 & 0.0824 & -0.0077 & 0.0566 & 0.0405 & -0.007 & 0.0002 \\
\hline & $\begin{array}{l}\text { Other self- } \\
\text { employed }\end{array}$ & Injury & Dowry & $\begin{array}{l}\text { Informal } \\
\text { loan }\end{array}$ & Bank loan & $\begin{array}{l}\text { Informal } \\
\text { loan } \\
\text { amount }\end{array}$ & $\begin{array}{l}\text { Bank } \\
\text { loan } \\
\text { amount }\end{array}$ & $\begin{array}{l}\text { MF loan } \\
\text { amount }\end{array}$ \\
\hline Other self-employed & 1 & & & & & & & \\
\hline Injury & 0.015 & 1 & & & & & & \\
\hline Dowry & -0.0793 & -0.0328 & 1 & & & & & \\
\hline Informal loan & -0.0426 & 0.1341 & 0.1486 & 1 & & & & \\
\hline Bank loan & -0.0312 & 0.0401 & -0.0199 & 0.0307 & 1 & & & \\
\hline Informal loan amount & -0.0536 & 0.1009 & 0.1559 & 0.7809 & -0.009 & 1 & & \\
\hline Bank loan amount & -0.0098 & 0.0514 & -0.0171 & 0.0289 & 0.8604 & -0.0081 & 1 & \\
\hline MF loan amount & 0.1798 & 0.0432 & 0.0017 & -0.0383 & 0.0046 & -0.016 & 0.0197 & 1 \\
\hline Size future loan & 0.1822 & 0.078 & 0.0057 & 0.0381 & 0.0473 & 0.0755 & 0.0612 & 0.552 \\
\hline Relatives own land & -0.0267 & 0.066 & -0.0255 & -0.0036 & -0.0103 & 0.0027 & -0.0072 & 0.1097 \\
\hline Land & -0.014 & -0.0237 & -0.065 & 0.0144 & -0.011 & 0.0359 & -0.0204 & 0.1389 \\
\hline Transfers: cash & 0.0491 & 0.0394 & -0.0123 & -0.0224 & -0.0164 & -0.0156 & -0.0141 & 0.0392 \\
\hline Transfers: food & 0.0093 & 0.0591 & -0.0078 & 0.0004 & -0.0103 & -0.0056 & -0.0089 & 0.0403 \\
\hline & $\begin{array}{l}\text { Size } \\
\text { future } \\
\text { loan } \\
\end{array}$ & $\begin{array}{l}\text { Relatives } \\
\text { own land }\end{array}$ & Land & $\begin{array}{l}\text { Transfers: } \\
\text { cash }\end{array}$ & $\begin{array}{l}\text { Transfers: } \\
\text { food }\end{array}$ & & & \\
\hline Size future loan & 1 & & & & & & & \\
\hline Relatives own land & 0.0915 & 1 & & & & & & \\
\hline Land & 0.1052 & 0.2844 & 1 & & & & & \\
\hline Transfers: cash & 0.0187 & 0.0718 & 0.081 & 1 & & & & \\
\hline Transfers: food & 0.0316 & 0.0609 & 0.1034 & 0.2524 & 1 & & & \\
\hline
\end{tabular}

